Web Jurnal:

http://ejournal.kemenperin.go.id/jli

\title{
Pengaruh alkalisasi pada pasta kakao terhadap rendemen minyak hasil pengempaan
}

\section{Effect of alkalization on cocoa paste on the yield of pressed oil}

\author{
Dewi Arziyah dan Sri Mutiar* \\ Program Studi Teknologi Industri Pertanian Universitas Dharma Andalas \\ Jl. Sawahan No.103 A Simpang Haru, Padang, Indonesia \\ *e-mail: srimutiar@gmail.com
}

\begin{tabular}{|c|c|}
\hline INFO ARTIKEL & ABSTRAK \\
\hline $\begin{array}{l}\text { Sejarah artikel: } \\
\text { Diterima : } \\
\text { 16 Maret } 2021 \\
\text { Direvisi : } \\
\text { 8 Desember } 2021 \\
\text { Diterbitkan : } \\
\text { 30 Desember } 2021\end{array}$ & $\begin{array}{l}\text { Tujuan dari penelitian ini adalah untuk mengetahui pengaruh alkalisasi dengan } \\
\text { menggunakan tiga senyawa kimia terhadap lemak kakao. Alkalisasi menggunakan } \\
\text { senyawa kimia } \mathrm{Na}_{2} \mathrm{CO}_{3}, \mathrm{~K}_{2} \mathrm{CO}_{3} \text { dan } \mathrm{Ca}(\mathrm{OH})_{2} \text { dengan konsentrasi masing-masingnya } \\
0,5 \%, 1 \%, 1,5 \%, 2 \% \text { dan } 2,5 \% \text {. Alkalisasi dan ukuran partikel adalah salah satu faktor } \\
\text { yang mempengaruhi pengolahan untuk menghasilkan cokelat berkualitas. Penelitian ini } \\
\text { menggunakan Rancangan Acak Lengkap (RAL) dengan tiga ulangan. Data dianalisis } \\
\text { menggunakan ANOVA untuk melihat perbedaan antar perlakuan. Data selanjutnya diuji } \\
\text { menggunakan Least Significant Difference pada tingkat signifikansi } 5 \% \text { untuk }\end{array}$ \\
\hline $\begin{array}{l}\text { Kata kunci: } \\
\text { alkalisasi; } \\
\text { minyak kakao; } \\
\text { pasta kakao; } \\
\text { pengempaan; }\end{array}$ & $\begin{array}{l}\text { menemukan karakteristik terbaik. Hasil penelitian menunjukkan bahwa ada pengaruh } \\
\text { interaksi antara jenis bahan kimia dengan konsentrasinya terhadap rendemen minyak } \\
\text { kakao, pH, dan analisis warna. Kombinasi perlakuan yang menghasilkan rendemen } \\
\text { tertinggi adalah penambahan alkali } \mathrm{Na}_{2} \mathrm{CO}_{3} \text { pada konsentrasi } 2,5 \% \text { dengan suhu } 80^{\circ} \mathrm{C} \\
\text { dengan rendemen } 35,33 \% \text {. }\end{array}$ \\
\hline
\end{tabular}

rendemen

\begin{abstract}
The purpose of this study was to determine the effect of alkalization using three chemical compounds on cocoa butter. Alkalization uses chemical compounds $\mathrm{Na}_{2} \mathrm{CO}_{3}, \mathrm{~K}_{2} \mathrm{CO}_{3}$ and $\mathrm{CaOH}_{2}$ with concentrations of $0.5 \%, 1 \%, 1.5 \%, 2 \%$ and $2.5 \%$, respectively. Alkalization and particle size are among the factors that influence processing to produce quality chocolate. This study used a completely randomized design with three replications. Data were analyzed using ANOVA to see differences between treatments. The data were then tested using Least Significant Difference at a significance level of 5\% to find the best characteristics. The results of statistical analysis showed a significant effect on cocoa oil yield. The results showed that there was an interaction effect between the type of chemical and its concentration on the yield of cocoa oil. The treatment combination that produced the highest yield was the addition of alkaline $\mathrm{Na}_{2} \mathrm{CO}_{3}$ at a concentration of $2.5 \%$ at a temperature of $80^{\circ} \mathrm{C}$ with a yield of $35.33 \%$
\end{abstract}

Keywords:

cocoa liquor;

cocoa oil;

alkalization;

yield;

pressing

C 2021 Penulis. Dipublikasikan oleh Baristand Industri Padang. Akses terbuka dibawah lisensi CC BY-NC-SA

\section{Pendahuluan}

Sumatera Barat merupakan salah satu daerah penghasil kakao. Produksi kakao yang berlimpah dapat meningkatkan pendapatan masyarakat jika diolah dalam bentuk produk setengah jadi maupun produk jadi (Arziyah, 2017). Salah satu cara meningkatkan nilai tambah dari produk kakao adalah mengolah biji kakao menjadi minyak kakao. Biji kakao yang merupakan bahan baku untuk membuat cokelat adalah biji dari tanaman kakao Theobroma.

Biji kakao mengandung lemak coklat sekitar $54 \%$. Secara umum, $100 \mathrm{~g}$ biji kakao jika diekstraksi akan menghasilkan $40 \mathrm{~g}$ cocoa butter, $40 \mathrm{~g}$ bubuk coklat 
(residu setelah ekstraksi yang masih mengandung 1024\% lemak) dan $20 \mathrm{~g}$ pengotor material (lapisan biji, kelembaban dan kotoran) (Miller et al., 2008). Biji kakao adalah bahan yang sangat penting dalam industri berbagai makanan seperti roti, biskuit, permen, dan lain sebagainya. Demikian juga dengan industri berbagai minuman seperti susu, kopi, dan sebagainya, kakao juga dibutuhkan untuk meningkatkan cita rasa (Dewi et al., 2012).

Federasi Pasar Perdagangan Kakao mengklasifikasikan lemak kakao sebagai lemak press cocoa, lemak cocoa expeller (diperas) dan lemak kakao olahan (olahan cocoa halus). Kualitas terbaik dimiliki oleh lemak tekan murni yang diproduksi dengan menekan pasta kakao hidraulik dari biji berkualitas baik (Afoakwa et al., 2013). Proses expeller, memberikan hasil lemak cocoa yang lebih rendah (80\%) dibandingkan dengan cocoa fat press (89\%). Cocoa butter yang dimurnikan melibatkan proses menekan ekstraksi hidrolik, expeller, dan pelarut dinetralkan dengan larutan alkalin dan warna dihilangkan, misalnya dengan menggunakan bentonit (Venter et al., 2012). Tekstur dari cocoa butter ini tergantung pada kandungan lemak jenuh dan tak jenuh yang terikat pada trigliserida dan pada kandungan asam lemak bebas (Guehi et al., 2008).

Minyak kakao memiliki peran penting, baik di industri cokelat itu sendiri maupun di industri lain. Salah satu manfaat minyak kakao adalah untuk aromatisasi cokelat dengan menyemprotkan bubuk coklat terutama dalam cokelat instan atau campurannya dengan minuman bubuk lainnya (Sihombing et al., 2018). Selain itu, minyak kakao juga bisa digunakan sebagai bahan penganan coklat, bahan kosmetik seperti make up, lipstik, krim pembersih, krim penghalus kulit, minyak rambut dan juga sebagai obat penyakit rematik.

Dalam industri pengolahan cokelat dilakukan penambahan alkali (Alkalisasi). Alkalisasi adalah salah satu cara untuk mendapatkan warna dan rasa bubuk kakao yang lebih baik, termasuk dalam industri pengolahan kakao (Widayat, 2013). Alkalisasi dilakukan dengan tujuan untuk meningkatkan rasa dan tampilan visual (warna) dari produk hilir yang dihasilkan. Penambahan bahan alkali juga dapat meningkatkan rendemen minyak yang dihasilkan (Inayati, 2015). Penambahan alkali berbeda- beda dalam tiap produk tergantung jenis produk yang dihasilkan, jadi bisa berbeda ketika alkalizing di pabrik pengolahan cokelat skala besar dan di pabrik pengolahan skala kecil (Hadi dan Siratunnisak, 2016).

Alkalisasi menyebabkan terjadinya perubahan $\mathrm{pH}$ dan menyebabkan struktur pasta berubah sehingga proses pengaliran lemak ketika pengempaan pasta dilakukan akan lebih mudah dan cepat (Sihombing et al., 2018). Alkalisasi dilakukan pada pasta kakao sebelum proses pemisahan minyak (Ramlah, 2016). Oleh karena itu perlu dilakukan penelitian untuk menentukan penggunaan konsentrasi alkali dalam proses alkalisasi terhadap rendemen minyak yang dihasilkan. Pengepresan pasta cokelat yang telah diberikan penambahan bahan alkali dengan beberapa variasi konsentrasi. Jenis alkali yang digunakan dalam penelitian ini adalah $\mathrm{Na}_{2} \mathrm{CO}_{3}, \mathrm{~K}_{2} \mathrm{CO}_{3}$ dan $\mathrm{CaOH}_{2}$.
Variasi konsentrasi digunakan setiap interval 0,5, mulai dari $0,5 \%$ hingga $2,5 \%$. Penentuan konsentrasi bertujuan untuk menentukan perbedaan dalam penggunaan konsentrasi minimum hingga konsentrasi maksimum.

Tujuan dari penelitian ini adalah untuk menganalisa pengaruh penambahan 3 bahan alkali $\left(\mathrm{Na}_{2} \mathrm{CO}_{3}, \mathrm{~K}_{2} \mathrm{CO}_{3}\right.$ dan $\left.\mathrm{CaOH}_{2}\right)$ dengan 5 tingkat konsentrasi $(0,5 \%, 1 \%$, $1,5 \%, 2 \%$ dan $2,5 \%$ ) terhadap rendemen minyak yang dihasilkan.

\section{Metode}

Bahan penelitian yang digunakan dalam penelitian ini adalah pasta kakao yang diperoleh dari salah satu agroindustri di Payakumbuh, Sumatera Barat. Bahan kimia yang digunakan adalah bahan alkali $\mathrm{Na}_{2} \mathrm{CO}_{3}$, $\mathrm{K}_{2} \mathrm{CO}_{3}$ dan $\mathrm{CaOH}_{2}$ dengan variasi konsentrasi $0,5 \%, 1 \%$, $1,5 \%, 2 \%$ dan $2,5 \%$. Alat yang digunakan dalam penelitian ini adalah alat kempa press hidrolik, EZ HunterLab Colourflex, $\mathrm{pH}$ meter dan alat-alat analisis lainnya.

\subsection{Rancangan penelitian}

Rancangan penelitian yang digunakan adalah Rancangan Acak Lengkap (RAL), dimana perlakuannya adalah 5 perlakuan untuk 3 jenis bahan alkali dan 3 kali ulangan, sehingga keseluruhan penelitian ini ada 45 satuan percobaan. Data dianalisa secara statistika dengan menggunakan ANOVA (Analysis of Variance) jika berbeda nyata, dilanjutkan dengan uji DNMRT (Duncans New Multiple Range Test) pada taraf nyata $5 \%$. Perlakuan yang diberikan adalah A: penambahan bahan alkali $0,5 \%$, B: penambahan bahan alkali 1\%, C: penambahan bahan alkali 1,5\%, D: penambahan bahan alkali $2 \%$, dan E: penambahan bahan alkali 2,5\%.

\subsection{Pelaksanaan penelitian dan pengamatan}

Tahap awal yang dilakukan dalam penelitian ini adalah pasta kakao ditimbang sebanyak 100 g sebanyak 45 satuan percobaan. Perlakuan penambahan bahan alkali, yaitu $\mathrm{Na}_{2} \mathrm{CO}_{3}, \mathrm{~K}_{2} \mathrm{CO}_{3}, \mathrm{CaOH}_{2}$, masing-masingnya dengan variasi konsentrasi 0,5\%,1\%, 1,5\%, 2\%, 2,5\% dan dilakukan dengan 3 ulangan. Pasta kakao yang sudah diberi perlakuan penambahan konsentrasi alkali selanjutnya dikempa dengan suhu $80^{\circ} \mathrm{C}$. Pengamatan dilakukan terhadap rendemen minyak hasil kempa adalah perhitungan rendemen, pengamatan nilai $\mathrm{pH}$ dan analisis warna dari masing-masing perlakuan.

\section{Analisis kadar rendemen}

Perhitungan rendemen bertujuan untuk mengetahui persentase hasil ekstrak kempa press dari 100 gram pasta kakao terhadap jumlah minyak yang dihasilkan seperti pada Rumus (1).

$$
\text { Rendemen }=\frac{\text { jumlah minyak yang dihasilkan }(\mathrm{g})}{\text { jumlah bahan sebelum diolah }(\mathrm{g})} \times 100 \%
$$




\section{Pengamatan nilai pH}

Pengukuran nilai $\mathrm{pH}$ dilakukan dengan menggunakan $\mathrm{pH}$ meter yang sudah distandardisasi terlebih dahulu dengan menggunakan larutan buffer $\mathrm{pH} 4$ dan $\mathrm{pH}$ 7. $\mathrm{pH}$ meter dihidupkan sampai dalam keadaan stabil, lalu elektroda dibilas dengan aquades kemudian dikeringkan dengan kertas tisu. Elektroda kemudian dicelupkan ke dalam larutan sampel, dibiarkan beberapa saat hingga angka $\mathrm{pH}$ meter stabil, kemudian nilai $\mathrm{pH}$ dicatat.

\section{Analisis warna}

Analisis warna minyak kakao dilakukan untuk menentukan distribusi warna (menampilkan nilai $\mathrm{L}^{*}, \mathrm{a}^{*}$, $\left.b^{*}\right)$. Nilai $L^{*}$ menyatakan kecerahan dengan nilai 0 (hitam) sampai 100 (putih). Nilai a* menyatakan cahaya pantul yang menghasilkan warna kromatik campuran hijau - merah dengan nilai merah $(+127)$ dan nilai hijau (-128). Nilai $b^{*}$ menyatakan warna kromatik campuran biru - kuning dengan nilai kuning (+127) dan nilai biru (128). Selanjutnya dilakukan analisis histogram windows untuk mendapatkan deskripsi warna tersebut.

\section{Hasil dan pembahasan \\ 3.1 Rendemen}

Pengepresan pasta kakao dilakukan dengan menggunakan alat kempa press. Selain tekanan, suhu juga mempengaruhi rendemen yang dihasilkan (Anoraga et al., 2019). Penelitian ini menggunakan alat kempa press dengan suhu $80^{\circ} \mathrm{C}$, menggunakan suhu tinggi rendemen minyak kakao lebih banyak dihasilkan. Rendemen lemak hasil pengempaan pasta kakao cenderung meningkat dengan meningkatnya suhu pasta (Septianti, 2016). Selanjutnya Venter et al., (2007) menyatakan bahwa suhu akan mempengaruhi rendemen pada proses pengepresan kakao. Hasil rendemen minyak dari masing-masing penambahan bahan alkali tersebut dapat dilihat pada Tabel 1. Hasil rendemen minyak kakao yang dihasilkan dengan penambahan bahan alkali yang berbeda jenis dan konsentrasinya memberikan hasil yang beragam.

Tabel 1.

Rendemen minyak kakao dengan penambahan bahan alkali

\begin{tabular}{llll}
\hline Perlakuan & \multicolumn{3}{c}{ Rendemen dengan penambahan bahan alkali } \\
\cline { 2 - 4 } & $\begin{array}{l}\mathrm{Na}_{2} \mathrm{CO}_{3} \\
(\%) \pm \mathrm{SD}\end{array}$ & $\begin{array}{l}\mathrm{K}_{2} \mathrm{CO}_{3} \\
(\%) \pm \mathrm{SD}\end{array}$ & $\begin{array}{l}\mathrm{CaOH}_{2} \\
(\%) \pm \mathrm{SD}\end{array}$ \\
\hline A: $0,5 \%$ & $32,23^{\mathrm{a}} \pm 0,31$ & $20,83^{\mathrm{a}} \pm 0,35$ & $25,09^{\mathrm{b}} \pm 0,22$ \\
B: $1 \%$ & $33,3^{\mathrm{ab}} \pm 0,46$ & $25,11^{\mathrm{b}} \pm 0,47$ & $27,90^{\mathrm{c}} \pm 0,13$ \\
C: $1,5 \%$ & $34,23^{\mathrm{bc}} \pm 0,38$ & $28,90^{\mathrm{cd}} \pm 0,12$ & $31,04^{\mathrm{d}} \pm 0,42$ \\
D: $2 \%$ & $33,83^{\mathrm{bc}} \pm 1,67$ & $31,02^{\mathrm{d}} \pm 0,47$ & $32,87^{\mathrm{e}} \pm 0,59$ \\
E: $2,5 \%$ & $35,33^{\mathrm{c}} \pm 0,12$ & $28,50^{\mathrm{cd}} \pm 1,07$ & $22,91^{\mathrm{a}} \pm 0,63$
\end{tabular}

Keterangan: Angka-angka pada lajur yang sama diikuti oleh huruf kecil yang tidak sama, berbeda nyata pada taraf $5 \%$ menurut Duncan's Multiple Range Test (DNMRT)

Hasil penelitian pengepresan pasta kakao dengan penambahan $\mathrm{Na}_{2} \mathrm{CO}_{3}$ menunjukkan hasil yang berbeda secara signifikan. Rendemen minyak yang tertinggi dihasilkan dengan perlakuan penambahan $\mathrm{Na}_{2} \mathrm{CO}_{3} 2,5 \%$, yaitu $35,33 \%$. Hal ini sesuai dengan hasil penelitian yang diungkapkan oleh (Noviyanty et al., 2018) bahwa semakin tinggi konsentrasi pelarut maka jumlah rendemen yang dihasilkan juga makin meningkat.

Hasil perolehan rendemen minyak dari pasta kakao yang telah diberi penambahan $\mathrm{K}_{2} \mathrm{CO}_{3}$ menunjukkan hasil yang berbeda dan signifikan. Rendemen minyak tertinggi diperoleh pada penambahan $\mathrm{K}_{2} \mathrm{CO}_{3}$ dengan konsentrasi $2 \%$, yaitu $31,023 \%$. Terjadi penurunan jumlah rendemen minyak yang dihasilkan pada penambahan $\mathrm{K}_{2} \mathrm{CO}_{3}$ dengan konsentrasi $2,5 \%$, yaitu $28,5 \%$. Penambahan konsentrasi $\mathrm{K}_{2} \mathrm{CO}_{3}$ yang terbaik adalah pada konsentrasi $2 \%$ dengan jumlah rendemen minyak $31,023 \%$.

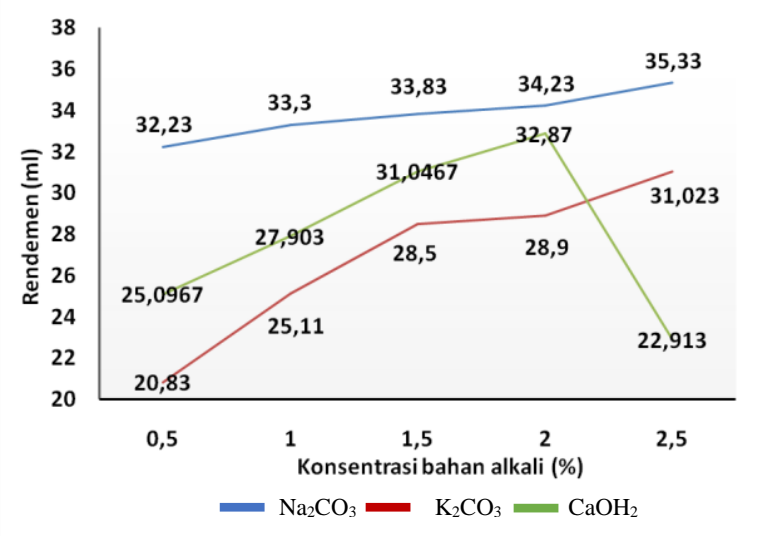

Gambar 1. Grafik jumlah rendemen $(\mathrm{ml})$ yang diperoleh dengan variasi penambahan bahan alkali (\%)

Hasil rendemen dengan penambahan $\mathrm{CaOH}_{2}$ menunjukkan hasil yang berbeda secara signifikan. Rendemen minyak yang tertinggi dihasilkan dengan perlakuan penambahan $\mathrm{CaOH}_{2} 2 \%$, yaitu $32,87 \%$. Terjadi penurunan jumlah rendemen minyak yang dihasilkan pada penambahan $\mathrm{CaOH}_{2}$ dengan konsentrasi $2,5 \%$, yaitu $22,91 \%$. Penambahan konsentrasi $\mathrm{K}_{2} \mathrm{CO}_{3}$ terbaik adalah pada konsentrasi $2 \%$ dengan jumlah rendemen minyak 32,87\%. Gambar 1 dapat dilihat bahwa penambahan bahan alkali terbaik adalah dengan penambahan $\mathrm{Na}_{2} \mathrm{CO}_{3}$. Peningkatan konsentrasi bahan alkali $\mathrm{K}_{2} \mathrm{CO}_{3}$ dan $\mathrm{CaOH}_{2}$ mengakibatkan penurunan jumlah minyak yang dihasilkan.

\subsection{Analisis pH}

Pengukuran $\mathrm{pH}$ dilakukan pada pasta cokelat yang telah diberi perlakuan penambahan bahan alkali dengan berbagai tingkat variasi konsentrasi. Hasil pengukuran dapat dilihat pada Tabel 2, dimana $\mathrm{pH}$ meningkat seiring dengan meningkatnya konsentrasi bahan alkali. Hal ini sesuai dengan pernyataan (Miller et al., 2008), melalui penambahan alkali, $\mathrm{pH}$ massa coklat meningkat sesuai dengan jumlah alkali yang diberikan dan batasan terbaik adalah 8,2 . 
Tabel 2.

Hasil analisis pH dengan penambahan bahan alkali Perlakuan Hasil Analisis pH Penambahan bahan alkali

\begin{tabular}{llll} 
& $\mathrm{Na}_{2} \mathrm{CO}_{3}$ & $\mathrm{~K}_{2} \mathrm{CO}_{3}$ & $\mathrm{CaOH}_{2}$ \\
\hline A: $0,5 \%$ & 7,4 & 11 & 9 \\
B: $1 \%$ & 7,4 & 11 & 9 \\
C: $1,5 \%$ & 7,8 & 12 & 9 \\
D: $2 \%$ & 8 & 12 & 10 \\
E: $2,5 \%$ & 8 & 12 & 11 \\
\hline
\end{tabular}

Dari grafik (Gambar 2) dapat dilihat bahwa $\mathrm{pH}$ masing-masing perlakuan menunjukkan peningkatan dengan bertambahnya pemberian konsentrasi alkali. Perlakuan dengan penambahan bahan alkali $\mathrm{K}_{2} \mathrm{CO}_{3}$ menghasilkan $\mathrm{pH}$ yang cukup tinggi, yaitu berkisar antara 11-12, sedangkan yang dialkalikan dengan $\mathrm{Na}_{2} \mathrm{CO}_{3}$ menunjukkan nilai yang menengah.

Nilai pH meningkat dan keasaman berkurang sebagai hasil dari perlakuan alkalisasi. Nilai $\mathrm{pH}$ bertambah secara proporsional dengan penambahan konsentrasi dan nilai keasaman menurun. Peningkatan $\mathrm{pH}$ disebabkan netralisasi asam bebas yang terjadi di cairan alami. Peningkatan $\mathrm{pH}$ akan mendukung pembentukan senyawa pencoklatan, karena deaminasi parsial protein (Rodríguez et al., 2009). Hal ini dikonfirmasi oleh analisis warna, yang menunjukkan konsentrasi alkali yang tinggi menghasilkan warna yang lebih gelap pada sampel (Serra and Coll, 2002).

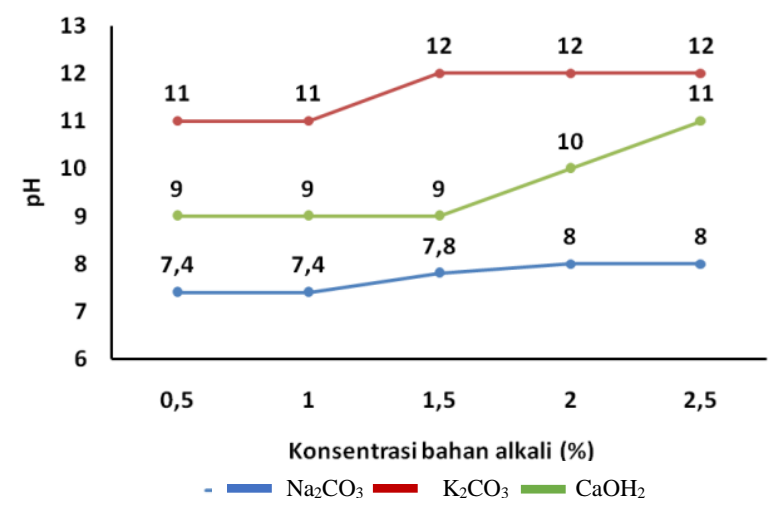

Gambar 2. Grafik pengaruh $\mathrm{pH}$ terhadap variasi penambahan bahan alkali

Perlakuan dengan penambahan bahan alkali $\mathrm{Na}_{2} \mathrm{CO}_{3}$ menghasilkan $\mathrm{pH}$ yang meningkat seiring dengan penambahan konsentrasi bahan alkali. Kisaran $\mathrm{pH}$ dengan bahan alkali $\mathrm{Na}_{2} \mathrm{CO}_{3}$ adalah 7,4-8. Menurut penelitian (Bukhari, 2018) $\mathrm{pH}$ biji kakao yang sudah diberi perlakuan alkalisasi cenderung mendekati netral dibandingkan yang tidak mendapat perlakuan alkalisasi, hal ini dikarenakan larutan alkali yang bersifat basa mengakibatkan $\mathrm{pH}$ menjadi lebih netral.

\subsection{Analisis warna}

Minyak kakao yang sudah diberi penambahan bahan alkali selanjutnya dilakukan uji warna. Warna minyak kakao diukur menggunakan alat EZ HunterLab Colourflex yang menghasilkan nilai $\mathrm{L}^{*}, \mathrm{a}^{*}(+), \mathrm{b}^{*}(+)$.
Nilai L* menunjukkan kecerahan warna, a* $(+)$; merah, $b^{*}(+)$ : kuning. Penentuan warna minyak kakao dapat dilihat pada Tabel 3, 4 dan 5 berikut ini.

Tabel 3.

Hasil pengukuran warna dengan penambahan bahan alkali $\mathrm{CaOH}_{2}$

\begin{tabular}{|c|c|c|c|c|c|}
\hline Perlakuan & $\mathrm{L}^{*}$ & $a^{*}$ & $b^{*}$ & $\begin{array}{l}\text { Warna } \\
\text { yang } \\
\text { dihasilkan }\end{array}$ & $\begin{array}{l}\text { Deskripsi } \\
\text { warna }\end{array}$ \\
\hline A1: $0,5 \%$ & 34,5 & 15,8 & 18,2 & & $\begin{array}{l}\text { Dark } \\
\text { vemilion }\end{array}$ \\
\hline A2: $1 \%$ & 30,1 & 17,7 & 9,5 & & $\begin{array}{l}\text { Dark } \\
\text { grayish } \\
\text { scarlet }\end{array}$ \\
\hline A3: $1,5 \%$ & 22,8 & 6,6 & 3,2 & & $\begin{array}{l}\text { Reddish } \\
\text { brownish } \\
\text { gray }\end{array}$ \\
\hline A4: $2 \%$ & 23,8 & 7,7 & 10,7 & & $\begin{array}{l}\text { Dark } \\
\text { grayish } \\
\text { tangelo }\end{array}$ \\
\hline A5: $2,5 \%$ & 38,8 & 8,8 & 5,9 & & $\begin{array}{l}\text { Dark } \\
\text { scarletish } \\
\text { gray }\end{array}$ \\
\hline
\end{tabular}

Keterangan:*) $\mathrm{L}^{*}=$ Ligthness/kecerahan, $\mathrm{a}^{*}=$ kemerahan $(+) /$ kehijauan $(-)$, dan $b^{*}=$ kekuningan $(+) /$ kebiruan $(-)$.

Tabel 4.

Hasil pengukuran warna dengan penambahan bahan alkali $\mathrm{K}_{2} \mathrm{CO}_{3}$

\begin{tabular}{llllll}
\hline Perlakuan & $\mathrm{L}^{*}$ & $\mathrm{a}^{*}$ & $\mathrm{~b}^{*}$ & $\begin{array}{l}\text { Warna } \\
\text { yang } \\
\text { dihasilkan }\end{array}$ & $\begin{array}{l}\text { Deskripsi } \\
\text { warna }\end{array}$ \\
\hline B1: $0,5 \%$ & 54,1 & 13,6 & 19,8 & & $\begin{array}{l}\text { Grayish } \\
\text { tangelo }\end{array}$ \\
B2: $1 \%$ & 46,8 & 10,6 & 15,2 & & $\begin{array}{l}\text { Grayish } \\
\text { tangelo }\end{array}$ \\
B3: $1,5 \%$ & 46,6 & 21,1 & 22,4 & & $\begin{array}{l}\text { Moderate } \\
\text { vermilion }\end{array}$ \\
& & & & & $\begin{array}{l}\text { Dark } \\
\text { grayish } \\
\text { vermilion }\end{array}$ \\
B4: $2 \%$ & 37 & 17,1 & 14,8 & & $\begin{array}{l}\text { Dark } \\
\text { grayish } \\
\text { crimson }\end{array}$ \\
\hline & & & & & \\
B5: $2,5 \%$ & 30,9 & 12,5 & 11,7 & & \\
\hline
\end{tabular}

Keterangan: $\left.{ }^{*}\right) \mathrm{L}^{*}=$ Ligthness/kecerahan, $\mathrm{a}^{*}=$ kemerahan $(+) /$ kehijauan $(-)$, dan $b^{*}=$ kekuningan $(+) /$ kebiruan $(-)$.

Tabel 3 menunjukkan bahwa semakin tinggi penambahan konsentrasi bahan alkali $\mathrm{CaOH}_{2}$ maka nilai L* (kecerahan) cenderung sedikit meningkat, terutama untuk konsentrasi $2,5 \%$. Tabel 4 dan 5 menunjukkan semakin tinggi penambahan konsentrasi bahan alkali $\mathrm{K}_{2} \mathrm{CO}_{3}$ dan $\mathrm{Na}_{2} \mathrm{CO}_{3}$, maka nilai $\mathrm{L}^{*}$ rendemen cenderung agak sedikit semakin menurun, sehingga warna rendemen agak sedikit gelap. Hal ini dipengaruhi oleh beberapa faktor diantaranya konsentrasi bahan alkali, 
$\mathrm{pH}$, cahaya, suhu dan waktu pengolahan produk (Delgado et al., 2000).

Nilai L* merupakan nilai yang menunjukkan tingkat kecerahan dengan kisaran nilai 0-100. Dari tabel di atas dapat diketahui kisaran nilai $\mathrm{L}^{*}$ rendemen minyak kakao berkisar antara 18,7-54,1. Nilai $\mathrm{L}^{*}$ tertinggi dengan penambahan $\mathrm{K}_{2} \mathrm{CO}_{3} 0,5 \%(54,1)$ dan nilai $\mathrm{L}^{*}$ terendah dengan penambahan bahan alkali $\mathrm{Na}_{2} \mathrm{CO}_{3} 0,5 \%(18,7)$. Hal ini terlihat warna dengan $\mathrm{L}^{*}$ yang rendah lebih gelap dari yang lainnya. Menurut (Rodríguez et al., 2009), efek pemanasan juga mengakibatkan saturasi warna kroma kuning berkurang sehingga warna akan menjadi sedikit gelap.

Tabel 5.

Hasil pengukuran warna dengan penambahan bahan alkali $\mathrm{Na}_{2} \mathrm{CO}_{3}$

\begin{tabular}{|c|c|c|c|c|c|}
\hline Perlakuan & $\mathrm{L}^{*}$ & $a^{*}$ & $b^{*}$ & $\begin{array}{l}\text { Warna yang } \\
\text { dihasilkan }\end{array}$ & $\begin{array}{l}\text { Deskripsi } \\
\text { Warna }\end{array}$ \\
\hline $\mathrm{C} 1: 0,5 \%$ & 25,5 & 28,6 & 13,9 & & $\begin{array}{l}\text { Reddish } \\
\text { brown }\end{array}$ \\
\hline $\mathrm{C} 2: 1 \%$ & 27,6 & 14,9 & 11,5 & & $\begin{array}{l}\text { Dark } \\
\text { grayish } \\
\text { vermilion }\end{array}$ \\
\hline C3: $1,5 \%$ & 32,6 & 6,4 & 3,7 & & $\begin{array}{l}\text { Dark } \\
\text { scarletish } \\
\text { gray }\end{array}$ \\
\hline C4: $2 \%$ & 38 & 6,7 & 14,1 & & $\begin{array}{l}\text { Dark } \\
\text { grayish } \\
\text { brown }\end{array}$ \\
\hline C5: $2,5 \%$ & 18,7 & 14 & 10,1 & & $\begin{array}{l}\text { Dark } \\
\text { scarlet }\end{array}$ \\
\hline
\end{tabular}

Keterangan:*) $\mathrm{L}^{*}=$ Ligthness/kecerahan, $\mathrm{a}^{*}=$ kemerahan $(+) /$ kehijauan $(-)$, dan $b^{*}=$ kekuningan $(+) /$ kebiruan $(-)$.

Nilai a* menunjukkan kisaran warna antara merah dan hijau dengan nilai positif (+) yang artinya merah dan nilai negatif (-) yang artinya hijau. Tabel 5 menunjukkan nilai a* positif dimana nilai a* tertinggi, yaitu 28,6 pada perlakuan penambahan bahan alkali $\mathrm{Na}_{2} \mathrm{CO}_{3} 0,5 \%$, dan nilai $\mathrm{a} *$ terendah terdapat pada penambahan bahan alkali $\mathrm{Na}_{2} \mathrm{CO}_{3} 1,5 \%$.

Berdasarkan hasil penelitian perlakuan warna dengan $\mathrm{Na}_{2} \mathrm{CO}_{3}$ pada konsentrasi $2,5 \%$ merupakan nilai $\mathrm{L}^{*}$ yang lebih tinggi. Hal ini menunjukkan warna minyak kakao lebih cerah dari yang lain dengan menggunakan tiga skala pengukuran: skala L mulai dari terang ke gelap, skala a untuk merah ke hijau, dan skala b untuk kuning ke biru (Miller et al., 2008). Perlakuan menambahkan $\mathrm{Na}_{2} \mathrm{CO}_{3} 2,5 \%$ dalam penelitian ini menunjukkan minyak kakao lebih terang dari yang lain dengan nilai L* lebih tinggi dari perlakuan lain.

\section{Kesimpulan}

Hasil penelitian ini dapat disimpulkan bahwa terdapat pengaruh alkalisasi yang signifikan dengan menggunakan tiga senyawa kimia terhadap rendemen, pengukuran $\mathrm{pH}$ dan warna minyak kakao. Kombinasi yang menghasilkan rendemen tertinggi adalah dengan menggunakan bahan alkali $\mathrm{Na}_{2} \mathrm{CO}_{3} 2,5 \%$ menghasilkan rendemen minyak yang cukup banyak, yaitu berkisar antara $35,3 \%$. Perlakuan dengan penambahan bahan alkali menghasilkan $\mathrm{pH}$ yang meningkat seiring dengan penambahan konsentrasi bahan alkali. Perlakuan dengan penambahan bahan alkali $\mathrm{K}_{2} \mathrm{CO}_{3}$ menghasilkan $\mathrm{pH}$ yang cukup tinggi, yaitu berkisar antara 11-12, tetapi perlakuan terbaik adalah menggunakan bahan alkali $\mathrm{Na}_{2} \mathrm{CO}_{3}$, yaitu dengan $\mathrm{pH} 7,4-8$. Perlakuan warna dengan $\mathrm{Na}_{2} \mathrm{CO}_{3}$ pada konsentrasi $2,5 \%$ merupakan nilai $\mathrm{L} *$ yang lebih tinggi. Ini menunjukkan warna minyak kakao lebih cerah dari yang lain.

\section{Ucapan terima kasih}

Terima kasih diucapkan kepada Kementerian Riset dan Teknologi Dikti Kontrak Penelitian No: 020/Add/ Kontrak-Penelitian/K10/KM/2018 sebagai sumber pendanaan penelitian melalui Hibah Penelitian Dosen Pemula dan semua pihak yang terlibat dalam penelitian ini.

\section{Daftar pustaka}

Afoakwa, E.O., Quao, J., Takrama, J., Budu, A.S., Saalia, F.K., 2013. Chemical composition and physical quality characteristics of Ghanaian cocoa beans as affected by pulp pre-conditioning and fermentation. J. Food Sci. Technol. 50, 1097-1105. https://doi.org/10.1007/s13197-011-0446-5

Anoraga, S.B., Wijanarti, S., Sabarisman, I., Sari, A.R., 2019. Optimasi suhu dan waktu pengepresan dalam pembuatan bubuk kakao pada skala kelompok tani. J. Ilm. Rekayasa Pertan. Dan Biosist. 7, 85-94. https://doi.org/10.29303/jrpb.v7i1.91

Arziyah, D., 2017. Analisis faktor keberhasilan agroindustri kakao berkelanjutan di Sumatera Barat menggunakan pendekatan fuzzy AHP. J. Teknol. Pertan. Andalas 21, 103. https://doi.org/10.25077/jtpa.21.2.103-109.2017

Bukhari, 2018. Pengaruh lama fermentasi dan pemberian natrium karbonat $\left(\mathrm{Na}_{2} \mathrm{CO}_{3}\right)$ pada mutu biji kakao (Theobroma cacao L.). J. Sains Ris. VIII, 46-57.

Delgado, -Vergas F, Jomenez R, Paredes-Lopez,O, 2000. Carotenoids, antocyanins and betalains Characteristics, biosynthesis, processing and stability. Rev. Food Sci. Nutr. 40, 173-289.

Dewi, K.H., Zuki, M., Subagio, M., 2012. Pengaruh suhu dan lama waktu penyangraian nibs terhadap mutu bubuk coklat. J. Agroindustri 2, 41-52.

Guehi, S.T., Dingkuhn, M., Cros, E., Fourny, G., Moulin, G., Vidal, A.C., 2008. Impact of cocoa processing technologies in free fatty acids formation in stored raw cocoa beans. Afr. J. Agric. Res. 3, 174179.

Hadi, A., Siratunnisak, N., 2016. Pengaruh penambahan bubuk coklat terhadap sifat fisik, kimia, dan organoleptik minuman instan bekatul. J. AcTion Aceh Nutr. J. 1, 121-129. 
Inayati, I., 2015. Pengaruh jenis dan konsentrasi alkali dalam pembuatan enriched RBO (Rice Bran Oil) pada tahap awal proses isolasi $\gamma$-Oryzanol. Ekuilibrium 14. https://doi.org/10.20961/ekuilibrium. v14i1.2138

Miller, K., Hurst, W.J., Payne, M.J., Stuart, D.A., Apgar, J., Swegart, D.S., Ou, B., 2008. Impact of alkalization on the antioxidant and flavanol content of commercial cocoa powders 8527-8533.

Noviyanty, A., Hasanuddin, A., Rahim, A., Hutomo, G.S., 2018. Optimalisasi ekstraksi kulit ari biji kakao pada berbagai konsentrasi pelarut sebagai sumber antioksidan. Presented at the Conference on Innovation and Application of Science and Technology (CIASTECH 2018, Universitas Widyagama, Malang, pp. 382-390.

Ramlah, S., 2016. Karakteristik mutu dan citarasa cokelat kaya polifenol. J. Ind. Has. Perkeb. 11, 2332. https://doi.org/10.33104/jihp.v11i1.3553

Rodríguez, P., Pérez, E., Guzmán, R., 2009. Effect of the types and concentrations of alkali on the color of cocoa liquor: Alkalization of cocoa liquor. J. Sci. Food Agric. 89, 1186-1194. https://doi.org/10.1002/ jsfa. 3573

Septianti, E., 2016. Pengaruh suhu pemastaan terhadap rendemen dan kadar lemak bubuk kakao hasil pengempaan dari biji kakao fermentasi dan non fermentasi. J. Penelit. Pascapanen Pertan. 13, 43-51.

Serra, B.J., Coll, F.V., 2002. Factors affecting the formation of alkylpyrazines during roasting treatment in natural and alkalinized cocoa powder. J Agric Food Chem 13, 43-50. https://doi.org/10.1021/ jf011597k

Sihombing, M., Puspita, D., Sirenden, M.T., 2018. Fragrance Formation in the of cocoa Roaster Process (Theobroma cacao) with Roaster Temperature variation Using a Vacuum Drying Oven. J. Kim. Sains Dan Apl. 21, 155-160.

Venter, M.J., N.J.M., K., A.B. de Haan, 2007. Modelling and experimental evaluation of high-pressure expression of cocoa nibs. J. Food Eng. 80, 11571170.

Venter, P.B., Senekal, N.D., Kemp, G., Amra-Jordaan, M., Khan, P., Bonnet, S.L., Van Der Westhuizen, J.H., 2012. Analysis of commercial proanthocyanidins. Part 3: The chemical composition of wattle (Acacia mearnsii) bark extract. Phytochemistry 83, 153-167. https://doi.org/10.1016/ j.phytochem.2012.07.012

Widayat, H.P., 2013a. Perbaikan mutu bubuk kakao melalui proses ekstraksi lemak dan alkalisasi. J. Teknol. Dan Ind. Pertan. Indones. 5, 12-16. 